\title{
JERZY RYSZARD HANDSCHKE (1948-2013)
}

In vita mors certa est... (w życiu tylko śmierć jest pewna). Po ludzku i ona pozostaje zwykle zaskoczeniem, zwłaszcza gdy umiera Ktoś tak pełen energii, entuzjazmu, woli życia, Kto roztacza wizje przyszłości i bogate plany. 13 grudnia 2013 r. odszedł od nas nasz Mistrz i Opiekun - ś.p. prof. dr hab. Jerzy Handschke, Kierownik Katedry Ubezpieczeń Uniwersytetu Ekonomicznego w Poznaniu. Profesor pozostawił po sobie nie tylko efekty swojej pracy naukowo-badawczej, ale przede wszystkich wyświadczoną ludziom dobroć.

Profesor był zawsze najpierw Człowiekiem, dopiero później Profesorem czy szefem. Takiego Go znaliśmy i takiego zapamiętamy - my wypromowani przez Niego doktorzy i doktoranci. Tak też chcemy o Nim napisać w tym wspomnieniu, bo jak powiedział Napoleon Bonaparte „Wszystko umiera, tylko pamięć dobrych uczynków nie ginie".

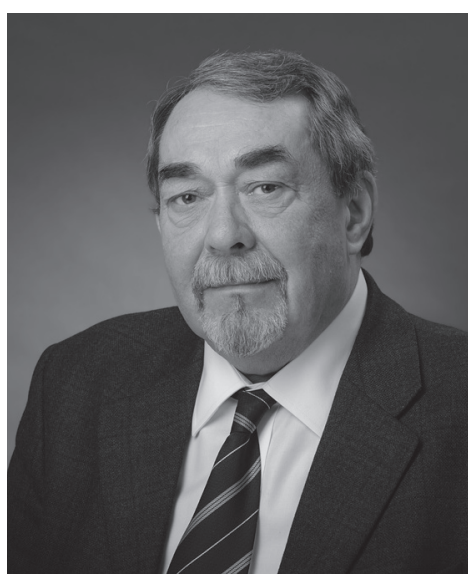

Profesor zostawiał nam dużo swobody, licząc na nasza dojrzałość i odpowiedzialność. Ufał nam, otwierał przed nami drzwi, usuwał z nami przeszkody, zachęcał, motywował. Nie ograniczał naszych horyzontów, pozwalał rozwijać skrzydła, jednocześnie dbając o to, by nasz „lot” był subtelnie kontrolowany. Był naszym przyjacielem, nauczycielem, doradca a przede wszystkim człowiekiem o wielkim sercu. Dawał poczucie bezpieczeństwa i stabilności, zarówno w życiu zawodowym, jak i prywatnym. Jego wiara w to, że damy radę pokonać niemal każdą trudność i możemy osiagnać niemal wszystko, dodawała nam sił, budziła z uśpienia, rozwiewała wątpliwości i motywowała do pracy. Bywało, że rozpoznawał nasz problem, nim my go nazwaliśmy. Co więcej - miał pomysł, jak go rozwiązać, nim cokolwiek zdążyliśmy powiedzieć.

Profesor nie przywiązywał wagi do tytułów. Dla niego liczył się drugi człowiek. Nie było ważne, jakie zajmuje stanowisko, iloma językami włada, co posiada... W kategoriach świata ktoś mógł nie być wielkim - dla Profesora był towarzyszem tej szczególnej chwili, w której człowiek spotyka się z człowiekiem, aby się wzajemnie ubogacić. Profesor był wyczulony na ludzkie nieszczęście. Dostrzegał potrzeby i pomagał ludziom realizować ich marzenia. Obdarowywał ludzi nie z tego, co zbywa, ale tak, jak obdarowałby sam siebie, czyli czymś najlepszym. Obdarowywał nie tylko materialnie, ale także ubogacał duchowo pokazując, że życie może być pasją. Pasjonowały Go podróże, jazz, kulinaria, sztuka, historia, wino. Po prostu pasjonowało Go życie.

Profesor nie wstydził się swoich uczuć i emocji. Jak mało kto potrafił je okazywać. I w tych emocjach był wyrazisty. Gdy kogoś lubił, to całym sobą. Całym sobą też bronił swoich racji. Tym bardziej więc będziemy wspominać nasze małe sukcesy, kiedy to udawało nam się przekonać Go do zmiany zdania.

Profesor był dla nas chodząca historią ubezpieczeń. Tak też nazywał sam siebie przy okazji rozmów o przeszłości. Poznał osobiście niemal wszystkich twórców współczesnych ubezpieczeń: profesorów Szymańskiego, Szpunara, Pokorzyńskiego, Warkałłę, Wąsiewicza, Górskiego. Planowaliśmy nagrać Jego wspomnienia. Nie zdążyliśmy...

Profesor Jerzy Handschke urodził się 5 marca 1948 r. w Rogoźnie Wielkopolskim. W tej miejscowości przeszedł też pierwsze etapy edukacji: szkołę podstawową (1961) oraz liceum ogólnokształcące (1965). W 1965 r. Profesor rozpoczą studia na Wydziale Ogólnoekonomicznym Wyższej Szkoły Ekonomicznej w Poznaniu (obecnie Uniwersytet Ekonomiczny). Po studiach magisterskich, ukończonych w 1970 r., został doktorantem w Zakładzie Ubezpieczeń Instytutu Ekonomiki Obrotu Towarowego i Usług Wyższej Szkoły Ekonomicznej. W 1975 r. obronił pracę doktorską Kryteria oceny jakości typu obowiazkowych ubezpieczeń rolnych (napisaną pod kierunkiem prof. dr. Lucjana Pokorzyńskiego), która uzyskała nagrodę Ministra Nauki Szkolnictwa Wyższego i Techniki.

W latach 1975-1978 Profesor Handschke był adiunktem Katedry Ubezpieczeń. W 1978 r. podjął się trudu zorganizowania Instytutu Ubezpieczeń i Prewencji na Wydziale Ekonomicznym 
Wyższej Szkoły Inżynierskiej w Radomiu (obecnie: Uniwersytet Technologiczno-Humanistyczny im. Kazimierza Pułaskiego w Radomiu), którego był również pierwszym dyrektorem. Funkcję tę pełnił do 1990 r. W 1991 r. na podstawie pracy Ubezpieczenia jako instrument polityki ekonomicznej w warunkach wspótczesnego socjalizmu, przygotowanej w Państwowej Akademii Finansów w Moskwie, uzyskał stopień doktora habilitowanego nauk ekonomicznych. W $1993 \mathrm{r}$. został ponownie zatrudniony na stanowisku adiunkta w Katedrze Ubezpieczeń ówczesnej Akademii Ekonomicznej w Poznaniu. W 1997 r. został profesorem nadzwyczajnym tej uczelni, a od 2005 r. pełnił w niej funkcję kierownika Katedry Ubezpieczeń. W latach 1996-2007 kierował także pracami Katedry Ubezpieczeń Wyższej Szkoły Bankowej w Poznaniu. W marcu 2013 r. Prezydent RP Bronisław Komorowski nadał dr. hab. Jerzemu Handschkemu, prof. nadzw. UEP tytuł naukowy profesora nauk ekonomicznych.

Zainteresowania badawcze Profesora dotyczyły: ubezpieczeń rolnych, pojęcia jakości ochrony ubezpieczeniowej i instrumentarium oceny tej jakości, prewencji ubezpieczeniowej, polityki ubezpieczeniowej w rozumieniu działalności państwa w zakresie ubezpieczeń oraz teoretycznych podstaw nauki o ubezpieczeniach (definicje, funkcje i zasady ubezpieczeń). Na dorobek naukowy Profesora Jerzego Handschkego składa się ponad 100 pozycji: rozdziałów w monografiach i podręcznikach, artykułów naukowych, redakcji naukowych. Poza tym Profesor był autorem ok. 300 recenzji wydawniczych opracowań naukowych z zakresu ubezpieczeń.

Pisząc o działalności twórczej i eksperckiej Profesora, nie sposób nie wspomnieć o Jego zaangażowaniu na rzecz doskonalenia prawa ubezpieczeniowego. Profesor darzył nauki prawne szacunkiem i szczególnym sentymentem. Nie był prawnikiem, miał jednak szeroką wiedzę prawniczą i świadomość prawną. Wielokrotnie powtarzał, że zgłębianie zagadnień prawnych poszerza horyzonty. Jego zainteresowania prawne znalazły odzwierciedlenie nie tylko w publikacjach naukowych, ale przede wszystkim w licznych ekspertyzach. Przygotował ich ponad 40, w tym dla sądów, prokuratur, Sejmu i Senatu. Wiele z nich zawierało wnioski de lege lata i de lege ferenda, które wpłynęły na kształtowanie krajowego prawa ubezpieczeniowego.

Pan Profesor Jerzy Handschke przez długie lata, w ramach różnorodnych zajęć dydaktycznych, kształtował umysły i serca młodzieży akademickiej. Do studentów, podobnie jak do swoich współpracowników, miał zawsze bezpośredni i serdeczny stosunek. Wyrazem osiagnięć Profesora na płaszczyźnie dydaktycznej są liczne nagrody i wyróżnienia uzyskane przez Jego seminarzystów w konkursach na najlepsze prace magisterskie i licencjackie. W sumie Profesor wypromował około 1200 magistrów i licencjatów. Zarazem był promotorem 9 prac doktorskich, w tym 5 uhonorowanych nagrodami w konkursach na szczeblu krajowym.

Aktywną działalność naukową i dydaktyczną Profesora dopełniało zaangażowanie w licznych instytucjach i gremiach. Profesor Handschke był redaktorem naczelnym „Wiadomości Ubezpieczeniowych”, członkiem Rady Programowej „Prac i Materiałów Wydziału Zarządzania Uniwersytetu Gdańskiego”, członkiem Rady Naukowej „Rozpraw Ubezpieczeniowych”, członkiem Komitetu Redakcyjnego Serii „Współczesne Ubezpieczenia” rekomendowanej przez Grupę PZU oraz The Geneva Association, a także wiceprezesem Izby Gospodarczej Ubezpieczeń i Obsługi Ryzyka, arbitrem Sądu Polubownego przy Rzeczniku Ubezpieczonych, przewodniczacym Rady Naukowej Fundacji Instytutu Zarządzania Ryzykiem Społecznym w Warszawie, członkiem Rady Nadzorczej PZU Życie S.A. (wiceprzewodniczacym Komitetu Audytu), członkiem Rady Ubezpieczonych przy Rzeczniku Ubezpieczonych, członkiem Prezydium Komisji ds. Etyki przy Polskiej Izbie Pośredników Ubezpieczeniowych i Finansowych oraz przewodniczącym Komisji Rewizyjnej PTE, oddział w Poznaniu. W latach 1981-1999 był wiceprzewodniczącym Sekcji Polskiej Międzynarodowego Stowarzyszenia Prawa Ubezpieczeniowego (AIDA). Był również członkiem The Board of Governors International Insurance Society, Inc.

Uznanie dla działalności naukowo-dydaktycznej Profesora wyrażają m.in. przyznane wyróżnienia i nagrody. Wśród nich wymienić należy chociażby nagrodę III stopnia Ministra Nauki, Szkolnictwa Wyższego i Techniki za osiagnięcia w badaniach naukowych (1975), nadanie tytułu doktora honoris causa Tarnopolskiej Akademii Gospodarki Narodowej (1994) czy nagrody zespołowe Rektora Akademii Ekonomicznej w Poznaniu za współautorstwo podręczników Vademecum pośrednika ubezpieczeniowego (1997) oraz Ubezpieczenia gospodarcze (1999), a także nagrody za osiagnięcia naukowe za współautorstwo książki Ubezpieczenia w gospodarce rynkowej, t. 4 (2003). Działalność naukowa Profesora doceniona została także przez rektorów innych, niż macierzysta, uczelni, czego wyrazem były przyznane nagrody (m.in. nagroda zespołowa II stopnia Rektora 
Szkoły Głównej Handlowej w Warszawie w dziedzinie działalności naukowej za książkę Społeczne aspekty rozwoju rynku ubezpieczeniowego (2011), nagroda zespołowa I stopnia za udział w pracach zespołu Wydziału Zarządzani Politechniki Warszawskiej za Ubezpieczenia: podręcznik akademicki (2011). Ostatnio nadane Profesorowi wyróżnienia to: Lider Edukacji Ubezpieczeniowej (2008), Człowiek Roku Ubezpieczeń (2008) oraz Nagroda Rzecznika Ubezpieczonych „Zasłużony dla konsumentów usług ubezpieczeniowych" (2010).

Profesor Jerzy Handschke był także wielokrotnie odznaczany, w tym odznaka „Za zasługi dla województwa radomskiego" (1984), Srebrnym Krzyżem Zasługi (1985), Medalem KEN (1986), srebrną i złotą Odznaka Honorowa Polskiego Towarzystwa Ekonomicznego (1985, 1989) oraz srebrną i złotą odznaką „Za zasługi dla finansów PRL” (1987, 1988). Uzyskał także nagrody Rektora Akademii Ekonomicznej w Poznaniu za szczególny wkład w proces dydaktyczny oraz działalność organizacyjną na rzecz Uczelni.

Ci, którzy znali Profesora, wiedzą że uwielbiał raczyć towarzystwo opowieściami i dowcipami. Jest wielce prawdopodobne, że Profesor chciałby, aby wspomnienie o Nim zakończyć jedna z takich anegdot. Ale któż potrafi opowiadać tak jak On? Zakończymy więc słowami Epikura: „Jeżeli człowiek będzie żył wedle swojej natury, nigdy nie będzie biedny, jeżeli zaś wedle ludzkich mniemań - nigdy nie będzie bogaty”. Profesor żył wedle swojej natury... był bogaty, a nadto szczęśliwy.

Profesorze, nie zapomnimy Twojej dobroci, wiary w nas, poczucia humoru, ciepłych słów, komplementów, których nie szczędziłeś, entuzjazmu, którym zarażałeś. Nie zapomnimy, tym bardziej że byłeś z nami taki, jak zawsze - roześmiany, otwarty, szczęśliwy, choć nieco bardziej sentymentalny - kilka godzin przed śmiercią podczas spotkania wigilijnego...

Pracownicy i doktoranci Katedry Ubezpieczeń Uniwersytetu Ekonomicznego w Poznaniu 